\title{
Cadmium and lead adsorption and desorption by coffee waste-derived biochars
}

\author{
Ruan Carnier $^{1}$ (D), Aline Renée Coscione ${ }^{1, \star}$ (D), Cleide Aparecida de Abreu ${ }^{1}$ (D), Leônidas Carrijo \\ Azevedo Melo ${ }^{2}$ (D), Andressa Ferreira da Silva ${ }^{1}$ (D) \\ 1. Instituto Agronômico rộ - Centro de Solos e Recursos Ambientais - Campinas (SP), Brazil. \\ 2. Universidade Federal de Lavras rọ́r - Departamento de Ciência do Solo - Lavras (MG), Brazil. \\ Received: May 14, 2021 | Accepted: Nov. 3, 2021 \\ Section Editor: Gabriel Constantino Blain \\ *Corresponding author: aline.coscione@sp.gov.br \\ How to cite: Carnier, R., Coscione, A. R., Abreu, C. A., Melo, L. C. A. and Silva, A. F. (2022). Cadmium and lead adsorption and desorption by \\ coffee waste-derived biochars. Bragantia, 81, e0622. https://doi.org/10.1590/1678-4499.20210142
}

\begin{abstract}
Biochar derived from coffee waste has been reported as a promising material for heavy metal sorption. However, if the intended use is environmental remediation, knowing the extent to which desorption may occur is critical. Thus, the objective of this work was to evaluate the efficiency of spent coffee ground (SCG) and coffee parchment (CP) biochars pyrolyzed at $700{ }^{\circ} \mathrm{C}$ under laboratory conditions, in the sorption of $\mathrm{Cd}$ and $\mathrm{Pb}$ from aqueous solutions, in a $\mathrm{pH}$ range from 2 to 10 , and their retention after an induced desorption process with a $2.9 \mathrm{pH}$ acetic acid solution. Both biochars were alkaline, and the initial $\mathrm{pH}$ of the solution had a large effect on the sorption capacity of SCG but a small effect on the sorption capacity of CP. The Pb sorption capacity was higher for CP $\left(18.6 \mathrm{mg} \cdot \mathrm{g}^{-1}\right)$ than for SCG $\left(11.4 \mathrm{mg} \cdot \mathrm{g}^{-1}\right)$, while both biochars had low Cd retention capacities $\left(1.18 \mathrm{mg} \cdot \mathrm{g}^{-1}\right)$. Coffee parchment also showed the highest Pb retention ( $30 \%$ to $87 \%$ ), while for $\mathrm{Cd}$ there was no difference between CP and SCG biochars. Our results showed that metal precipitation was the main mechanism for metal immobilization and CP biochar proved to be more reliable than SCG, mainly for Pb, due to its higher sorption capacity and lower metal release by desorption than SCG. These characteristics are particularly important for the use of biochar in environmental remediation. Besides that, the biochar production represents an eco-friendly destination for these feedstocks, contributing to the circular economy.
\end{abstract}

Key words: environmental contamination, heavy metals, remediation, biosorbents.

\section{INTRODUCTION}

The increase in environmental contamination by heavy metals due to anthropogenic activities is a global issue that requires attention. Heavy metals pose high environmental risks due to their high toxicity and bioaccumulative potential (Xu et al. 2018). Moreover, their persistence in the environment affects ecosystem productivity and the economy (Lahori et al. 2017). Heavy metals such as $\mathrm{Zn}$ and $\mathrm{Cu}$ are also nutrients; however, they become toxic at high levels. Other elements, such as $\mathrm{Cd}$ and $\mathrm{Pb}$, do not have biological functions and are potentially toxic even at low levels (Nazir et al. 2015). Prolonged human exposure to $\mathrm{Cd}$ and $\mathrm{Pb}$ can damage the bones and kidneys and negatively affect the central nervous system and fertility (Kumar et al. 2020; Wang et al. 2018).

Chemical precipitation, membrane filtration, and ionic exchange are some of the traditional techniques utilized in the remediation of heavy metal-polluted areas and are usually expensive (Abdel-Raoulf et al. 2017). Among alternative techniques, heavy metal sorption by different sorbents has proven to be an effective and low-cost approach (Tomczyk et al. 2019). Thus, using biochars as biosorbents has been widely reported in the scientific literature (Fdez-Sanromán et al. 2020; Jiang et al. 2016; Zhang et al. 2018). Sorption of heavy metals by biochars occurs due to their high aromaticity and surface area, functional groups, and alkalinity. These properties make biochars viable and effective materials to immobilize organic and inorganic pollutants (Bian et al. 2014). 
Sorption occurs when the metal (sorbate) is retained on the biochar's solid surface (sorbent). This is a complex process and may involve different mechanisms, such as surface complexation (chemisorption), electrostatic attraction (physisorption), cation exchange, and precipitation (Hoslett et al. 2019). These mechanisms, in turn, are influenced by several factors associated with biochar properties. The high surface area of biochars contributes to metal retention and immobilization (Beesley et al. 2011). In addition, biochar is commonly alkaline, which influences heavy metal sorption by electrostatic interactions and precipitation (Wang S. et al. 2015). $\mathrm{pH}$ is one of the main factors that influences metal sorption because it alters metal speciation and the sorbent surface (Meng et al. 2018). $\mathrm{pH}$ also influences the desorption and reavailability of metals due to their greater mobility under acidic conditions. The influence of $\mathrm{pH}$ on sorption and desorption depends on the metal species, composition and characteristics of the adsorbent, mainly on surface charges (Nascimento et al. 2014).

Several feedstocks may be used for biochar production, such as agricultural residues, sewage sludge, animal manures, and others (Zeng et al. 2018; Zhao et al. 2018; Zhou et al. 2017). Nevertheless, from an environmental and economic point of view, using biomass with no defined final use seems more interesting. This is the issue of coffee industry waste, which is produced in large amounts (Veiga et al. 2017). It is estimated that approximately 1.1 ton of waste is generated for each ton of processed grains (Dias et al. 2014). Most coffee wastes are composed of coffee husks and spent coffee grounds (SCGs) (Blinová et al. 2017). Although coffee wastes are gaining other uses as byproducts (e.g., in the food industry) (Klingel et al. 2020), their proper final disposal is still challenging, and thus, the use of coffee wastes for biochar production to immobilize heavy metals becomes even more meaningful.

A significant reduction of uranium $(\mathrm{U}(\mathrm{VI}))$ in aqueous solution employing biochar, produced at $850{ }^{\circ} \mathrm{C}$ from coffee espresso waste, was observed by Paschalidou et al. (2020). López et al. (2020) evaluated biochar produced at $550^{\circ} \mathrm{C}$ from coffee husks and verified the immobilization of $\mathrm{Cd}$ in aqueous solution mainly due to the effect of precipitation. Chwastowski et al. (2020) observed the efficiency of SCG biochar in the removal of $\mathrm{Mn}, \mathrm{Pb}$ and $\mathrm{Cd}$ from aqueous solutions, which was more significant than that obtained for raw biomass. Stylianou et al. (2020), characterizing different biochars, found that SCG biochar had a high carbon content and aromaticity and was viable for environmental applications such as metal remediation.

However, most studies related to coffee waste-derived biochar did not evaluate if and to which extent metal desorption can occur. Knowledge of how much metal remains sorbed is ultimate if the intended use of biochar is environmental remediation. Toxicity characteristic leaching procedure (TCLP) is a soil sample extraction method for chemical analysis employed as an analytical method to simulate leaching through a landfill. It simulates a worst-case scenario under environmental conditions submitting the sample to an induced desorption process with a $2.9 \mathrm{pH}$ acetic acid solution (USEPA 1992).

Thus, considering the high availability of coffee waste and the potential of its biochars in the remediation of metals, the objective of this study was to evaluate the efficiency of SCG and coffee parchment (CP) biochars in the sorption of Cd and $\mathrm{Pb}$ from aqueous solution in a $\mathrm{pH}$ range from 2 to 10 , their retention after an induced sorption process by TCLP and after results comparison, to indicate the most promising one.

\section{MATERIAL AND METHODS}

\section{Biochar production and characterization}

The biomasses of SCGs and CP for the production of SCG and CP biochars, respectively, were obtained from the cities of Três Pontas and Varginha, respectively, in the state of Minas Gerais, Brazil. Pyrolysis was carried out in an electric drag bed thermochemical reactor, with six resistors. The pyrolysis process occurred at a heating rate of $5{ }^{\circ} \mathrm{C} \cdot \mathrm{min}^{-1}$ to $700{ }^{\circ} \mathrm{C}$ and a holding time of $1 \mathrm{~h}$, followed by slow cooling to room temperature. The biochars were then characterized in terms of their physicochemical characteristics, as briefly described below.

The $\mathrm{pH}$ was measured in a 1:10 (biochar:water) extract (Singh et al. 2017), and the elemental composition (C, N, H) was obtained by dry combustion in an elemental analyzer (IBI 2015). The ash content was determined at $750{ }^{\circ} \mathrm{C}$ in a muffle furnace (IBI 2015), and the organic carbon (OC) was obtained by digestion with dichromate and determined by titration (Nelson and Sommers 1996). The results of these analysis described above were expressed in $\%(\mathrm{~m} / \mathrm{m})$. The cation exchange 
capacity (CEC) was measured by the modified procedure of ammonium acetate compulsory displacement, as described by Domingues et al. (2017). These analyzes were performed in triplicate.

The surface area and pore size distribution were obtained by BET- $\mathrm{N}_{2}$ (Brunauer et al. 1938) and to illustrate the porous surface of the biochars, scanning electron microscopy (SEM) images were obtained using a Leo 440i model. The SEM images were zoomed at $100 \mu \mathrm{m}(150 \times)$ for both biochar samples. More details on the biochars characterization can be seen in our previous study (Sertoli et al. 2019).

\section{Sorption and desorption of $\mathrm{Cd}$ and $\mathrm{Pb}$ by biochars}

The metal sorption capacity of the SCG and CP biochars was evaluated using two experiments. First, the effect of pH was tested, maintaining a fixed concentration of $\mathrm{Cd}$ or $\mathrm{Pb}$ and the desorption test was carried out in sequence in the metalloaded-biochars. Second, a batch experiment was performed to obtain the maximum sorption of $\mathrm{Cd}$ or $\mathrm{Pb}$ for both biochars by Langmuir (1916) and Freundlich (1906) adsorption isotherms, with no pH adjustment. The metal concentration used in the experiments was determined by previous tests (data not shown) with literature support (Pathirana et al. 2019; Penido et al. 2019; Sertoli et al. 2019; Wang R.-Z. et al. 2018; Zhang et al. 2018).

\section{pH effect on biochar sorption and desorption}

To evaluate the influence of $\mathrm{pH}$ on the sorption of metals, $\mathrm{Cd}$ and $\mathrm{Pb}$ were tested separately in the $\mathrm{pH}$ range from 2 to 10 based on Penido et al. (2019) proposed assay for $\mathrm{pH} 2,4,6,8$ and 10. Cadmium and $\mathrm{Pb}$ solutions were prepared at 16 and $100 \mathrm{mg} \cdot \mathrm{L}^{-1}$, respectively, using $\mathrm{Cd}\left(\mathrm{NO}_{3}\right)_{2} \cdot 4 \mathrm{H}_{2} \mathrm{O}$ and $\mathrm{Pb}\left(\mathrm{NO}_{3}\right)_{2}$ dissolved in an electrolyte support solution of $0.01 \mathrm{~mol} \cdot \mathrm{L}^{-1} \mathrm{Ca}\left(\mathrm{NO}_{3}\right)_{2} \cdot 4 \mathrm{H}_{2} \mathrm{O}$. The $\mathrm{pH}$ of the solution containing $\mathrm{Cd}$ or $\mathrm{Pb}$ was adjusted using $0.1 \mathrm{~mol} \cdot \mathrm{L}^{-1} \mathrm{HCl}$ or $0.1 \mathrm{~mol} \cdot \mathrm{L}^{-1}$ $\mathrm{NaOH}$ solutions, as necessary. Afterwards, $0.04 \mathrm{~g}$ of each biochar was added to $25 \mathrm{~mL}$ centrifuge tubes containing $10 \mathrm{~mL}$ of each metal-pH combination. The resulting sample was stirred for $24 \mathrm{~h}$ in a bench shaker. After the stirring time, samples were centrifuged at $5000 \mathrm{rpm}$ for $10 \mathrm{~min}$, and the supernatants were extracted with a syringe and filtered $(\varnothing=0.22 \mu \mathrm{m})$ to determine the final/equilibrium $\mathrm{pH}$ and the contents of $\mathrm{Cd}$ and $\mathrm{Pb}$. A pH meter (model Orion Star A211) was used for $\mathrm{pH}$ measurement. The $\mathrm{Cd}$ and $\mathrm{Pb}$ concentrations in the supernatants were determined by inductively coupled plasma optical emission spectroscopy (ICP-OES) in Varian Vista MPX ${ }^{\mathrm{T}}$ equipment (axial view).

The contents of $\mathrm{Cd}$ and $\mathrm{Pb}$ sorbed by the biochars were calculated from the difference between their initial concentration and their equilibrium concentration after the sorption process (Uchimiya et al. 2011), as indicated by Eq. 1:

$$
\mathrm{q}_{\mathrm{s}}=\frac{\mathrm{V}_{\mathrm{s}}}{\mathrm{m}}\left(\mathrm{c}_{\mathrm{i}}-\mathrm{c}_{\mathrm{s}}\right)
$$

where $\mathrm{q}_{\mathrm{s}}\left(\mathrm{mg} \cdot \mathrm{g}^{-1}\right)$ is the amount of sorbed $\mathrm{Cd}$ and $\mathrm{Pb}, \mathrm{V}_{\mathrm{s}}(\mathrm{mL})$ is the volume added of the $\mathrm{Cd}$ and $\mathrm{Pb}$ solution, $\mathrm{m}(\mathrm{mg})$ is the added mass of biochar, and $\mathrm{c}_{\mathrm{i}}$ and $\mathrm{c}_{\mathrm{s}}\left(\mathrm{mg} \cdot \mathrm{L}^{-1}\right)$ are the initial and equilibrium concentrations of metals in solution, respectively.

Afterwards, $0.04 \mathrm{~g}$ of $\mathrm{Cd}$ - or Pb-sorbed biochars $(0.04 \mathrm{~g})$ were dried in an oven at $60 \pm 5{ }^{\circ} \mathrm{C}$ for $24 \mathrm{~h}$ and submitted to the induced desorption process according to the TCLP (US-EPA 1992). After drying, the samples were stirred for $24 \mathrm{~h}$ in a bench shaker with $10 \mathrm{~mL}$ of $0.1 \mathrm{~mol} \cdot \mathrm{L}^{-1}$ acetic acid at $\mathrm{pH} 2.9 \pm 0.1$. The supernatants were separated by centrifugation and the concentrations of $\mathrm{Cd}$ and $\mathrm{Pb}$ were determined by ICP-OES, as described before.

\section{Isotherm experiment}

Solutions containing $0,1.0,2.0,4.0,8.0$ and $16.0 \mathrm{mg} \cdot \mathrm{L}^{-1} \mathrm{Cd}$ or $0,20,60,100,140$ and $180 \mathrm{mg} \cdot \mathrm{L}^{-1} \mathrm{~Pb}$ were prepared using the same electrolyte support solution and salts as described for the $\mathrm{pH}$ experiment. The sorption experiment was performed by the addition of $0.05 \mathrm{~g}$ of the biochars tested to $50 \mathrm{~mL}$ centrifuge tubes containing $40 \mathrm{~mL}$ of each metal solution (Sertoli et al. 2019). Stirring, filtration and metal determination in the supernatants were performed as described before. No $\mathrm{pH}$ adjustment was performed on the metal solutions or the resulting sample after biochar addition. 
To obtain the adsorption isotherms for the biochars, batch sorption experiments were carried out. The amount of Cd and $\mathrm{Pb}$ sorbed by the SCG and the CP biochars was calculated by Eq. 1. The mean values of sorbed amounts for each concentration were fitted to the Langmuir (1916) and Freundlich (1906) nonlinear isotherms, indicated by Eqs. 2 and 3, respectively:

$$
\begin{gathered}
q_{s}=\frac{q_{\max } K_{L} C e}{1+K_{L} C e} \\
q_{s}=K_{F} C^{\frac{1}{n}}
\end{gathered}
$$

where $\mathrm{q}_{\mathrm{s}}\left(\mathrm{mg}^{\mathrm{g}} \mathrm{g}^{-1}\right)$ is the amount of the sorbed metal, Ce is the metal concentration in the solution at equilibrium after the sorption process, $\mathrm{q}_{\max }\left(\mathrm{mg} \cdot \mathrm{g}^{-1}\right)$ and $\mathrm{K}_{\mathrm{L}}$ are the maximum sorption capacity and the affinity constant of the Langmuir model, respectively, and $\mathrm{K}_{\mathrm{F}}$ and $1 / \mathrm{n}$ are constants of the Freundlich model.

\section{Data analysis}

Sorption data as a function of the $\mathrm{pH}$ were subjected to analysis of variance to verify the effect of each $\mathrm{pH}$ on $\mathrm{Cd}$ or $\mathrm{Pb}$ sorption. When a significant effect of $\mathrm{pH}$ was identified, the mean values of the sorption and equilibrium $\mathrm{pH}$ data were submitted to regression analysis. ANOVA and means comparison by the Tukey's test were used for the desorption data experiment. The software StatSoft - Statistica v. 10 was used for Langmuir and Freundlich adsorption isotherm modeling for each metal, considering the values of $\mathrm{R}^{2}$ and $\mathrm{p}(\mathrm{p} \leq 0.05)$ as indicators of data fitting quality.

\section{RESULTS AND DISCUSSION}

\section{Characterization of biochars}

Both the SCG and CP biochars are alkaline with pH values of 9.5 and 9.6, respectively (Table 1). This is a common characteristic of biochar, especially those produced at higher pyrolysis temperatures, due to the formation of oxides, hydroxides, and carbonates of basic cations ( $N a, K, C a$ and $\mathrm{Mg}$ ) (Singh et al. 2010). In solution, the pH changes the speciation of metals (In this case, $\mathrm{Pb}$ and $\mathrm{Cd}$ ) and the degree of protonation/deprotonation of functional groups present on the surface of biochars (Wu et al. 2019), which influences heavy metal mobility and availability (Lahori et al. 2017).

Table 1. Physical-chemical characteristics of the biochars.

\begin{tabular}{ccc}
\hline \multirow{2}{*}{ Attribute } & \multicolumn{3}{c}{ Biochar } \\
\cline { 2 - 3 } & SCG & CP \\
\hline $\mathrm{pH}$ (water) & $9.5 \pm 0.3$ & $9.6 \pm 0.1$ \\
\hline $\mathrm{C}(\%)$ & $62.3 \pm 2.7$ & $69.3 \pm 1.6$ \\
$\mathrm{~N}(\%)$ & $2.10 \pm 0.23$ & $1.57 \pm 0.1$ \\
\hline $\mathrm{H}(\%)$ & $1.48 \pm 0.1$ & $1.55 \pm 0.1$ \\
\hline Ashes $(\%)$ & $37.7 \pm 3.4$ & $13.6 \pm 0.5$ \\
\hline $\mathrm{OC}(\%)$ & $31.9 \pm 0.8$ & $38.5 \pm 1.8$ \\
\hline $\mathrm{H} / \mathrm{OC}$ & $0.56 \pm 0.1$ & $0.48 \pm 0.1$ \\
\hline $\mathrm{CEC}\left(\mathrm{mmol} \cdot \mathrm{cg}^{-1}\right)$ & $34.4 \pm 0.1$ & $275.8 \pm 8.7$ \\
\hline
\end{tabular}

$\mathrm{SCG}=$ Spent coffee grounds; $\mathrm{CP}=$ Coffee parchment; $\mathrm{OC}=$ Organic carbon; $\mathrm{CEC}=$ Cation exchange capacity. Numbers after the \pm signal indicate the standard deviation $(n=3)$.

The H/OC ratio is related to thermochemical changes in biochar since as lower it is, the biochar aromaticity of biochars increases, which in turn brings stability to the material (IBI 2015). For use in heavy metal remediation biochar stability is 
an important characteristic as it assures remediation will last over time (Ronsse et al. 2013). The CEC was much higher for CP biochar than for SCG. A similar CEC value was also obtained by Domingues et al. (2020) with coffee husk biochar at $750{ }^{\circ} \mathrm{C}$, which was indicated to improve soil fertility and have the potential for heavy metal immobilization.

The surface area varied from 32 to $45 \mathrm{~m}^{2} \cdot \mathrm{g}^{-1}$ for the CP and SCG biochars (Fig. 1a and b), with a predominance of mesopores (Figs. 1 and 2). The presence of mesopores favors ions transportation to active sorption sites (Cuong et al. 2019), increasing the effectiveness and speed of the sorption process (Hassan et al. 2021). The surface area plays an important role in metal sorption since this is a surface phenomenon (Nascimento et al. 2014) and can vary widely, even among close feedstocks. For example, the values described here for SCG and CP biochars are higher than the $1.53 \mathrm{and} 5.0 \mathrm{~m}^{2} \cdot \mathrm{g}^{-1}$ reported by Stylianou et al. (2020) and Jagdale et al. (2019) respectively, for SCG biochars pyrolyzed at 550 and $700{ }^{\circ} \mathrm{C}$. However, these values are close to the $34 \mathrm{~m}^{2} \cdot \mathrm{g}^{-1}$ reported for coffee ground biochar pyrolyzed at $400{ }^{\circ} \mathrm{C}$ (Liu and Huang 2018).

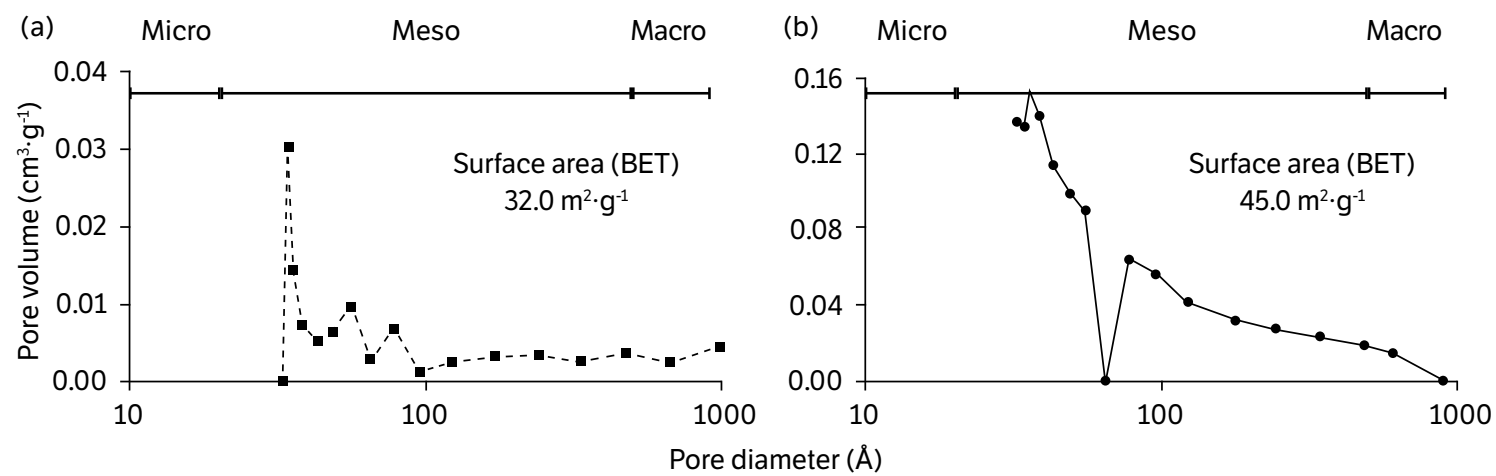

Figure 1. Surface area (BET) and pore size distribution for $C P(a)$ and SCG (b) biochars.

Source: Elaborated by the authors.
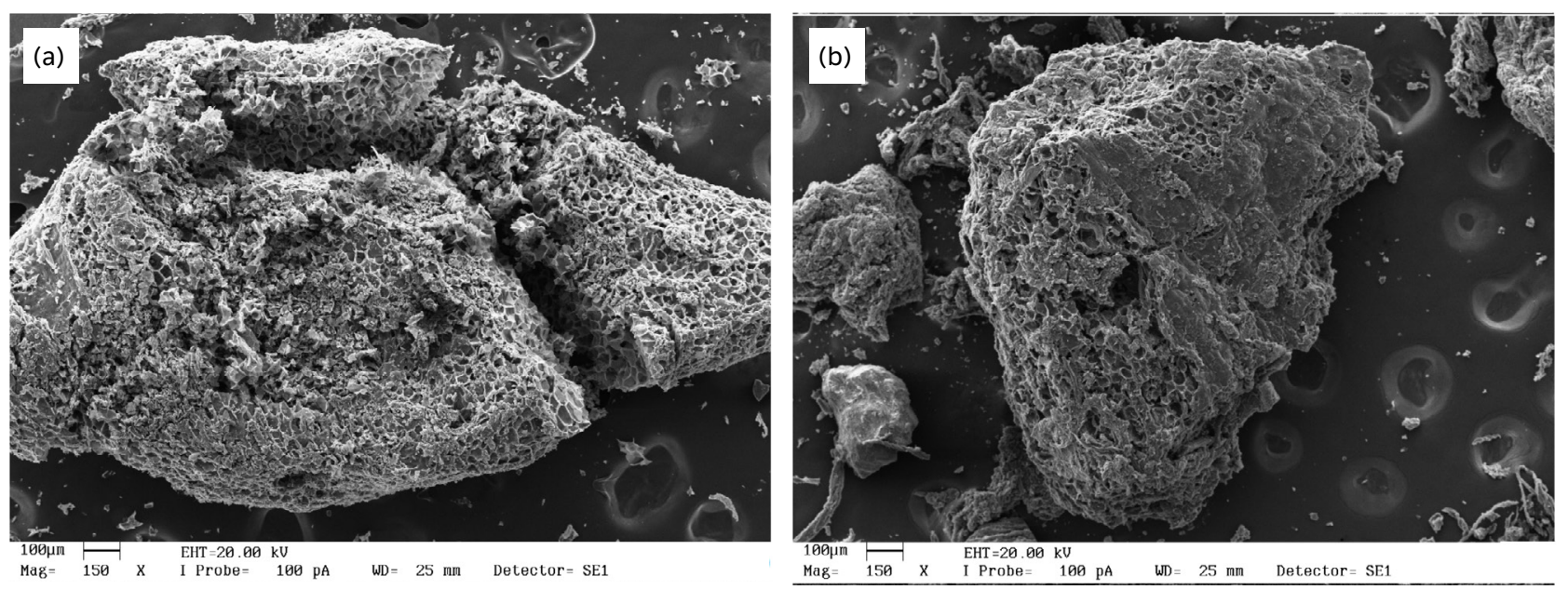

Figure 2. SEM images with a zoom of $150 \times$ for the CP (a) and the SCG (b) biochars.

Source: Elaborated by the authors.

In addition to the surface area size, the characteristics of this surface, such as the presence of chemical functional groups, have a substantial effect on the biochar sorption capacity for heavy metals. In our previous study (Sertoli et al. 2019), we found that the both biochars have oxygenated groups, but CP showed more aromatic structures, which is consistent with its $\mathrm{H} / \mathrm{OC}$ ratio. Therefore, these characteristics increase the stability and contribute to the resistance to the decomposition of this material (Sohi et al. 2010). Nevertheless, these structures present lower polarity than aliphatic structures, which results in a lower density of negative charges on the biochar surface (Uchimiya et al. 2011). Thus, it is possible to infer that $\mathrm{CP}$ biochar tends to present a lower negative charge density than SCG biochar. 


\section{Sorption and desorption of $\mathrm{Cd}$ and $\mathrm{Pb}$ by biochars}

\section{pH effect on biochar sorption and desorption}

Cadmium and $\mathrm{Pb}$ sorption were directly proportional to the $\mathrm{pH}$ increase (Fig. 3), and both biochars were efficient in the removal of both metals, with significant linear adjustment. Coffee parchment biochar showed a higher $\mathrm{Pb}$ and $\mathrm{Cd}$ sorption capacity than SCG biochar (Fig. 3a and b), except for pH 10. The final solution pH (Fig. 3c and d) has a direct relation with the results of metal sorption. The values of metals sorbed for the final $\mathrm{pH}$ between 2 and 4 , can be related to the presence of carboxylic groups in biochar that dissociate even in acidic $\mathrm{pH}$ (Kulikowska et al. 2015) and therefore can immobilize metals. Nevertheless, a buffering effect of CP biochar can be observed when compared to SCG biochar. Except for $\mathrm{pH}$ 2, CP biochar maintained the solution $\mathrm{pH}$ at approximately 8.0, unlike the SCG biochar, which presented a final solution $\mathrm{pH}$ proportional to the initial $\mathrm{pH}$ for both heavy metals. This neutralization effect was also observed by Huang et al. (2018) with chicken manure biochar pyrolyzed at $700{ }^{\circ} \mathrm{C}$, and they attributed the buffering capacity to the presence of alkaline ions $\mathrm{PO}_{4}^{3-}$ and $\mathrm{CO}_{3}^{2-}$ in the biochar.

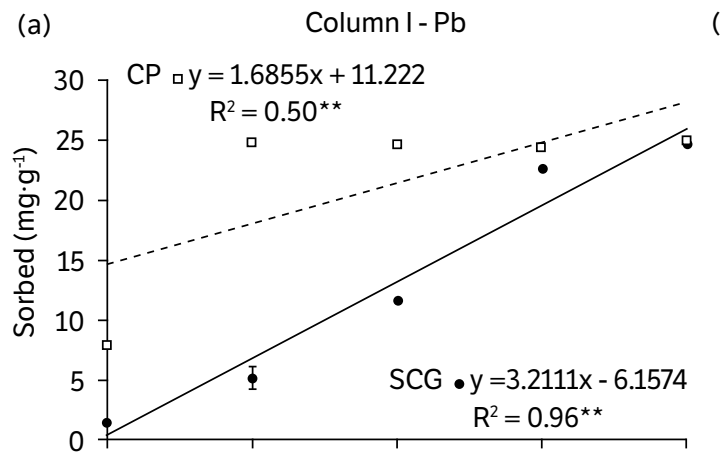

(b) Column II - Cd

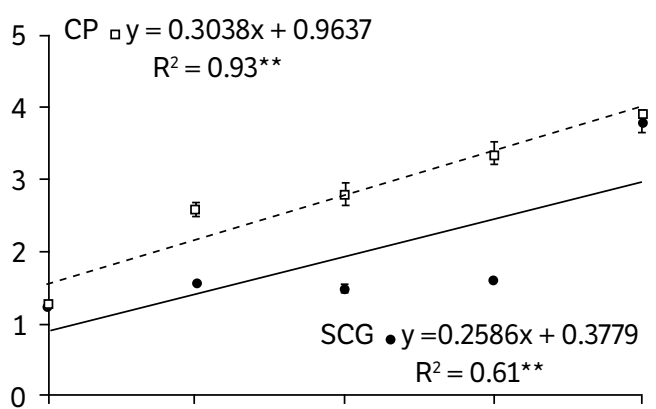

(c)

(d)
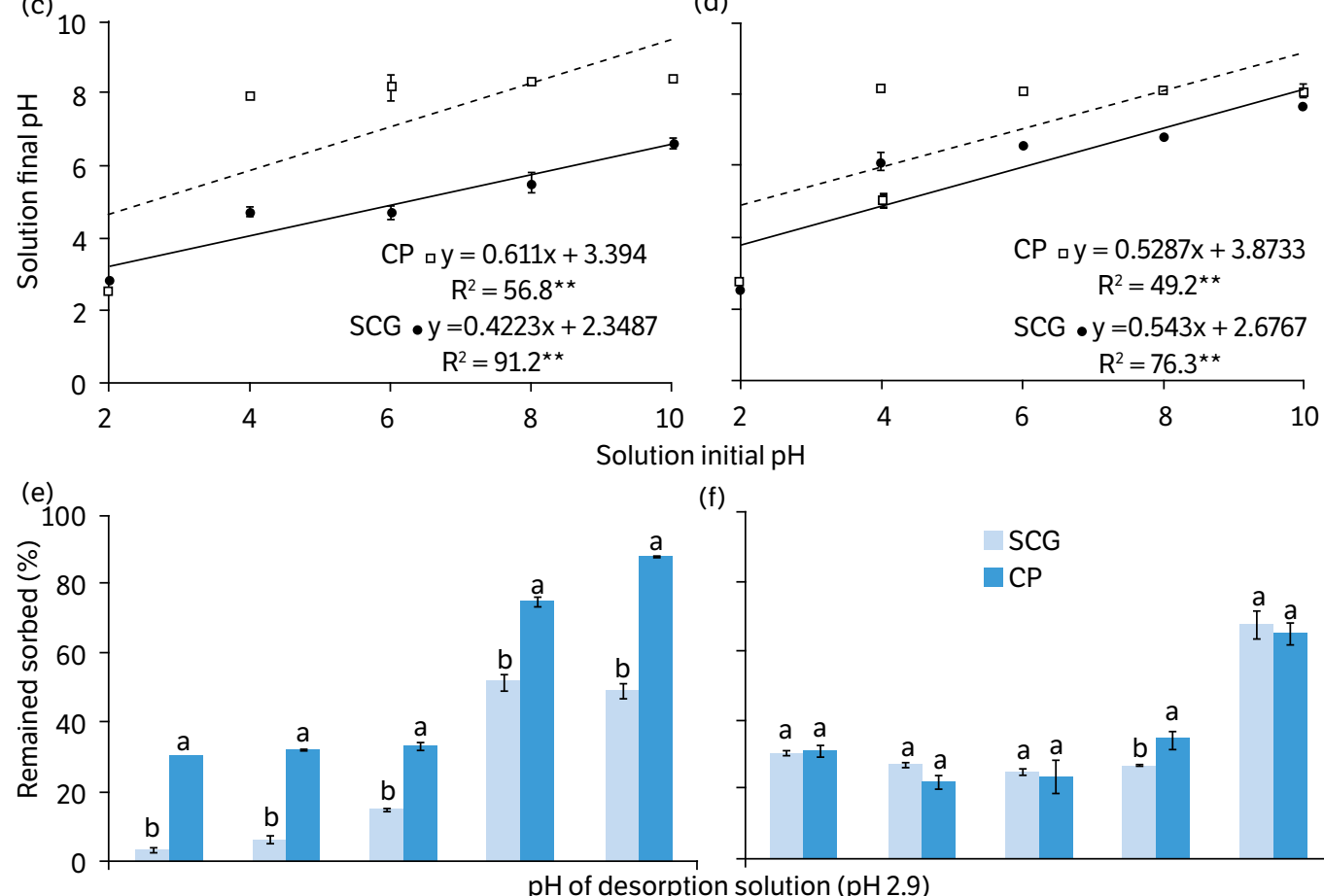

(f)

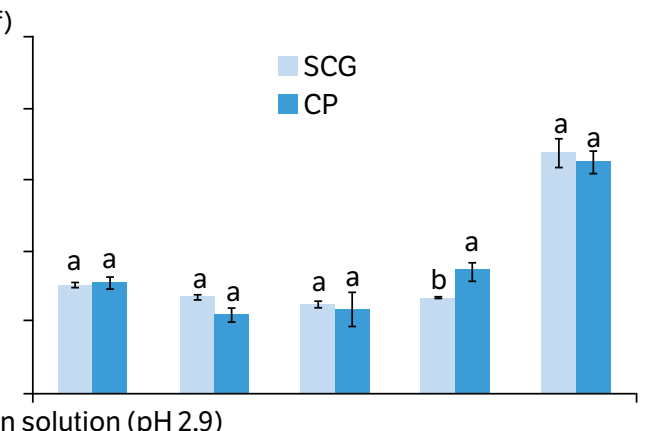

Figure 3. Amounts of lead and cadmium sorbed ( $a$ and $b$, respectively) and their respective final $\mathrm{pH}$ in solution ( $\mathrm{c}$ and $\mathrm{d}$ ) as a function of the initial pH. Amounts of lead and cadmium that remained sorbed after desorption test (e and $f$ ).

Note. ${ }^{* *}$ Significant regression $(p \leq 0.05)$. Horizontal columns with the same letter are not different for each metal by Tukey’s test $(p \leq 0.05)$. Bars indicate the standard deviation $(n=3)$. Source. Elaborated by the authors. 
Given the aromaticity and other characteristics of these biochars in the implications for the availability of negative charge, mainly for CP (Sertoli et al. 2019), when comparing with other sorption mechanisms, precipitation may have played a key role in the $\mathrm{Cd}$ and $\mathrm{Pb}$ sorption observed, which relates to solution speciation that is $\mathrm{pH}$ dependent. For cadmium, $\mathrm{Cd}^{2+}$ ions are the predominant species below $\mathrm{pH}$ 8.0, when they start to precipitate as $\mathrm{CdCO}_{3}$ and represent up to $60 \%$ of the $\mathrm{Cd}$ species in solution at $\mathrm{pH} 9.0$ (Wu et al. 2019). For lead, the free $\mathrm{Pb}^{2+}$ species predominates up to $\mathrm{pH}$ 6.0, when the $\mathrm{PbOH}^{+}$ion starts to form (Huang et al. 2017). However, from $\mathrm{pH} 7.0 \mathrm{~Pb}$ starts to precipitate as $\mathrm{PbCO}_{3}$, reaching $80 \%$ of the species in solution at $\mathrm{pH} 8.5$ (Wu et al. 2019). The precipitated form $\mathrm{Pb}(\mathrm{OH})_{2}$ also starts to be formed at $\mathrm{pH} 8.0$ (Huang et al. 2017). Therefore, increasing the solution $\mathrm{pH}$ favored precipitation and might explain the higher metal sorption capacity of CP than SCG biochar (Fig. 3a and b). The pH increase reduces the mobility of heavy metals in contaminated soil and water after treatment with coffee waste biochars (Kim et al. 2014). Chromium and Cd removal in the solution by precipitation caused by rice straw biochar has also been observed by other authors (Qian et al. 2016).

Thus, considering a greater effect of precipitation on the sorption of $\mathrm{Cd}$ and $\mathrm{Pb}$ by the biochars, manly $\mathrm{CP}$, the release of metals due to the acidification of the medium can occur through desorption (Uchimiya et al. 2011). In this work, the content of $\mathrm{Pb}$ that remained sorbed after desorption at $\mathrm{pH} 2.9$ ranged from $2.7 \%$ to $51 \%$ and from $30 \%$ to $87 \%$ for the SCG and CP biochars respectively (Fig. 3e). For the Cd, the content ranged from $24 \%$ to $67 \%$ SCG and from $21 \%$ to $64 \%$ for the SCG and CP biochars respectively (Fig. 3f). Therefore, the highest desorption rates for Pb were obtained for SCG biochar (Fig. 3e), and for Cd there was practically no difference between the biochars (Fig. 3f).

In these results, there is a clear effect of the equilibrium $\mathrm{pH}$ of the medium (Fig. $3 \mathrm{c}$ and $\mathrm{d}$ ) on the content of the metals that remained sorbed after acidification in the desorption step (Fig. 3e and $\mathrm{f}$ ), mainly for $\mathrm{Pb}$. Given the principle of precipitation, it can be seen that a portion of the complexes formed in basic or alkaline $\mathrm{pH}$ did not dissociate in acid $\mathrm{pH}$ (2.9). It is more evident for the $\mathrm{CP}$ biochar in relation to $\mathrm{Pb}$, in which at least $30 \%$ remained absorbed which increases to $87 \%$ when the initial sorption occurred at basic $\mathrm{pH}$. It is also noted, however, that at least about $20 \%$ of the Cd remained immobilized by both biochars. Metals sorbed by precipitation and complexation are desorbed less intensely than those that are retained by simple electrostatic attraction, ion exchange or physical sorption (Bandara et al. 2020).

The probable cause of $\mathrm{Pb}$ to have remained immobilized more intensely may be related to the species formed during sorption on biochar surface. Anions associated with minerals remaining on the biochars' surface (i.e., $\mathrm{CO}_{3}^{-}, \mathrm{PO}_{4}^{3-}, \mathrm{SO}_{4}^{2-}$ and $\mathrm{OH}^{-}$) may allow the formation of compounds with the metals, favoring precipitation (Wang et al. L. 2019; Wu et al. 2019), which in turn is influenced by the $\mathrm{pH}$ of the medium. Such ions are often found in high $\mathrm{pH}$ biochar ashes. For example, $\mathrm{Pb}$ precipitates (e.g., $\mathrm{PbCO}_{3}$ and $\mathrm{Pb}(\mathrm{OH})_{2}$ ) at $\mathrm{pH}$ values below those observed for $\mathrm{Cd}$, which remains as $\mathrm{Cd}^{2+}$ even in alkaline medium (Wu et al. 2019). In addition, $\mathrm{PbSO}_{4}$, which remains precipitated even at acidic $\mathrm{pH}$, can also be formed, and $\mathrm{PbCO}_{3}$ has an almost tenfold lower solubility constant $\left(\mathrm{K}_{\text {sp }}\right)\left(1.5 \times 10^{-13}\right)$ than $\mathrm{CdCO}_{3}\left(5.2 \times 10^{-12}\right)$ (Sengupta et al. 2017), which might contribute to some extent. Furthermore, $\mathrm{Cd}$ is known to be more soluble and mobile, preferring exchangeable fractions (Tabelin et al. 2018). Zama et al. (2017) observed a higher desorption rate for $\mathrm{Cd}$ due to the retention mechanisms involved in precipitation and electrostatic attraction, while for $\mathrm{Pb}$ precipitation, the formation of stable complexes with functional groups caused greater $\mathrm{Pb}$ stability and reduced desorption.

These results are very important from an environmental perspective, since even under acidity conditions, in which the mobility of metals is greater, part of the $\mathrm{Cd}$ and $\mathrm{Pb}$ remained sorbed by the biochars. Uchimiya et al (2011) evaluated the sequential desorption of $\mathrm{Cu}$ using synthetic rain water $(\mathrm{pH} 4.5)$ and acetate buffer solution $(\mathrm{pH}$ 4.9) $\mathrm{n}$ soils with and without the presence of biochar derived from broiler litter manure, pyrolyzed at $700^{\circ} \mathrm{C}$. The authors found that acetic acid provided the highest desorption rates and that this rate was reduced in the presence of biochar. In the present study, desorption was carried out at an even lower $\mathrm{pH}$ (2.9) and the fraction that remained absorbed was proportional to the increase in the initial $\mathrm{pH}$ of the medium (Fig. $3 \mathrm{e}$ and $\mathrm{f}$ ). Based on these results and considering that the biochars evaluated are alkaline and have a characteristic buffer effect, mainly of $\mathrm{CP}$, the metals tend to remain sorbed by the biochars applied in remediation processes. This characteristic is particularly important and advantageous in cases such as acid mine drainage, which are one of the main environmental problems around the planet due to the high acidity, metal content and the challenges involved in the treatment (Naidu et al. 2019). 


\section{Sorption isotherm experiment}

Langmuir and Freundlich isotherms showed a favorable shape for $\mathrm{Pb}$ sorption (Inglezakis and Poulopoulos 2006) (Fig. 4a) and, for both CP and SCG biochars, a significant fit in the models was obtained ( $\mathrm{p} \leq 0.05)$ (Table 2). The favorable isotherms indicate that a large adsorbate mass (metal) is retained by a unit mass of adsorbent (biochar) (Nascimento et al. 2014). The best fit for $\mathrm{Pb}$ was obtained by the Langmuir model, with an $\mathrm{R}^{2}$ of 0.98 for both biochars, which suggests a relatively homogeneous sorption surface and a monolayer when saturated (Araújo et al. 2018). The interaction between the metals and the biochars can be inferred by the $\mathrm{K}_{\mathrm{L}}$ and 1/n constants of the Langmuir and Freundlich models, respectively, which are related to the bonding energy. The higher the $\mathrm{K}_{\mathrm{L}}$ value is, the higher the affinity between the biochar and metal, while for the $1 / \mathrm{n}$ constant, values lower than 1 indicate a strong interaction between the metal and the biochar (Nascimento et al. 2014). Lead sorption by biochar also fitted the Freundlich model, resulting in a complex process; thus, the process is not limited to a monolayer system (Park et al. 2013).

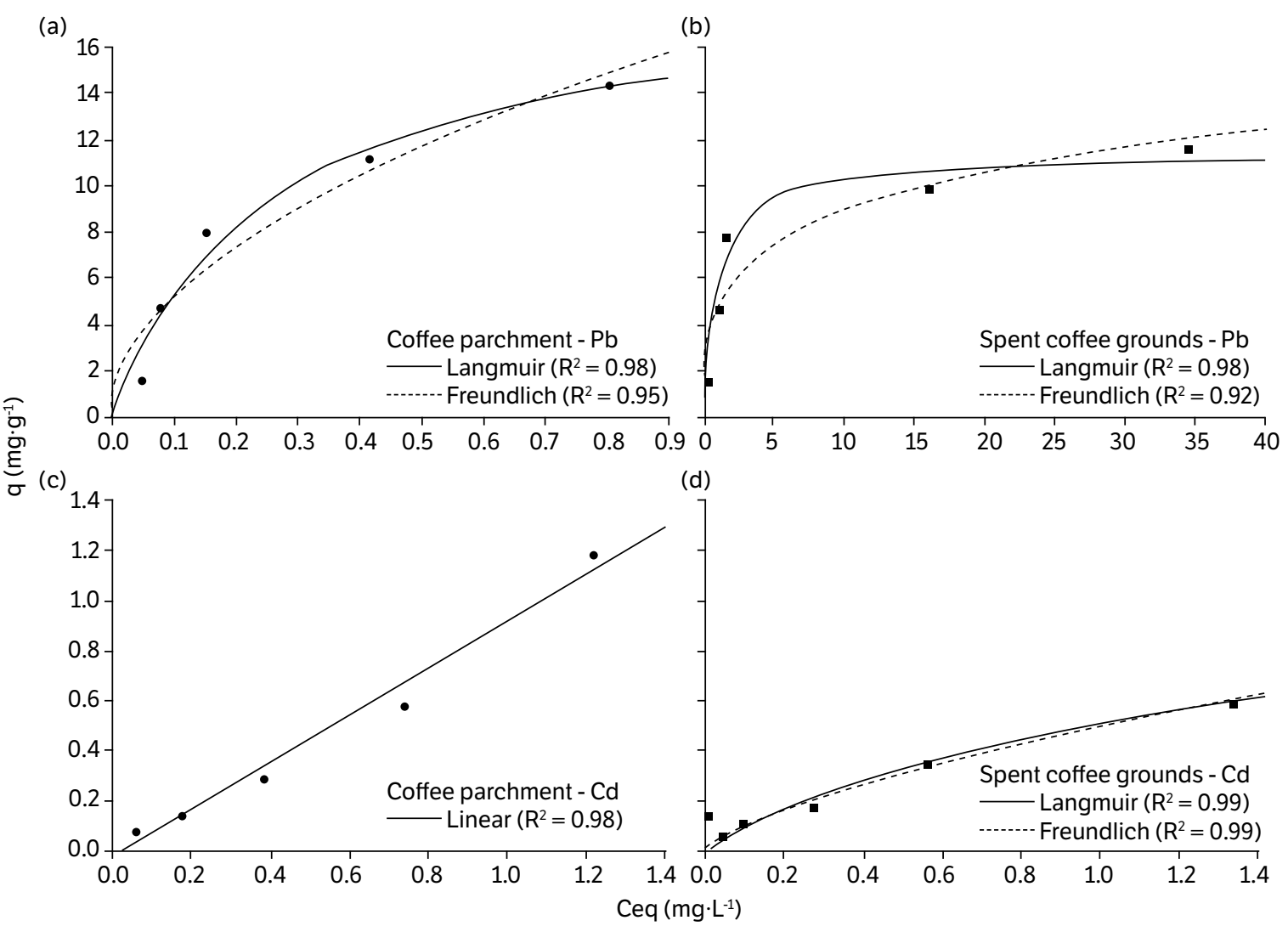

Figure 4. Lead and Cd adsorption isotherms for the CP ( $a$ and $c$ ) and SCG (b and d) biochars, respectively.

Source. Elaborated by the authors.

Table 2. Langmuir and Freundlich isotherm parameters for $\mathrm{Cd}$ and $\mathrm{Pb}$ sorbed by the biochars.

\begin{tabular}{|c|c|c|c|c|c|c|}
\hline \multirow{3}{*}{ Biochar } & \multicolumn{6}{|c|}{$\mathrm{Pb}$} \\
\hline & \multicolumn{3}{|c|}{ Langmuir } & \multicolumn{3}{|c|}{ Freundlich } \\
\hline & $\mathbf{R}^{2}$ & $\mathbf{q}_{\max }$ & $K_{L}$ & $\mathbf{R}^{2}$ & $K_{f}$ & $1 / n$ \\
\hline SCG & 0.98 & $11.41^{\star \star}$ & $0.99^{\star \star}$ & 0.92 & $5.13^{\star \star}$ & $0.24^{\star \star}$ \\
\hline \multirow[t]{2}{*}{$\mathrm{CP}$} & 0.98 & $18.61^{\star \star}$ & $4.02^{\star \star}$ & 0.95 & $16.58^{\star \star}$ & $0.49^{\star \star}$ \\
\hline & \multicolumn{6}{|c|}{ Cd } \\
\hline \multirow[t]{2}{*}{ Biochar } & \multicolumn{3}{|c|}{ Langmuir } & \multicolumn{3}{|c|}{ Freundlich } \\
\hline & $\mathbf{R}^{2}$ & $\mathbf{q}_{\max }$ & $K_{L}$ & $\mathbf{R}^{2}$ & $K_{f}$ & $1 / n$ \\
\hline SCG & 0.99 & $1.18^{\star \star}$ & $0.12^{\star \star}$ & 0.99 & $0.14^{\star \star}$ & $0.67^{\star \star}$ \\
\hline $\mathrm{CP}$ & \multicolumn{6}{|c|}{ Linear; $\mathrm{R}^{2}=0.98$} \\
\hline
\end{tabular}

SCG = Spent coffee grounds; $\mathrm{CP}=$ Coffee parchment; ${ }^{* *}$ Significant parameters $(p \leq 0.05)$. 
The maximum sorption capacity $\left(\mathrm{q}_{\max }\right)$ of $\mathrm{Pb}$ varied from 11.4 to $18.6 \mathrm{mg} \cdot \mathrm{g}^{-1}$ for the $\mathrm{SCG}$ and CP biochars, respectively. These values found for SCG and CP biochars are higher than $7 \mathrm{mg} \cdot \mathrm{g}^{-1}$ obtained for barley straw biochar (Jazini et al. 2018), and the result for CP biochar is close to $22.3 \mathrm{mg} \cdot \mathrm{g}^{-1}$, found for Pb removal in aqueous solution by SCGs biochar pyrolyzed at $700{ }^{\circ} \mathrm{C}$ (Chwastowski et al. 2020). However, both values are lower than $28.9 \mathrm{mg} \cdot \mathrm{g}^{-1}$ for corn straw biochar (Chi et al. 2017) and substantially lower than the $109 \mathrm{mg} \cdot \mathrm{g}^{-1}$ found for wheat straw (Kwak et al. 2019). For Cd, CP biochar followed a linear trend, and it was not possible to obtain a significant fit in the Langmuir and Freundlich isotherms (Fig. 4c), while for SCG biochar, both isotherm models fit the data $\left(\mathrm{R}^{2}=0.99\right)$ (Table 2$)$ and resulted in a maximum sorption capacity of $1.18 \mathrm{mg} \cdot \mathrm{g}^{-1}$. The amount of $\mathrm{Cd}$ absorbed by the biochars was also substantially lower than those reported in previous works. Chwastowski et al. (2020) found a sorption capacity of $19.4 \mathrm{mg} \cdot \mathrm{g}^{-1}$ for Cd by SCG biochar pyrolyzed at $700{ }^{\circ} \mathrm{C}$. The sorption capacity presented by Yin et al. (2019) for Pennisetum sp. straw biochar was $41.8 \mathrm{mg} \cdot \mathrm{g}^{-1}$. Li et al. (2017), who also studied straw-derived biochar pyrolyzed at $600{ }^{\circ} \mathrm{C}$, found a high value of $149 \mathrm{mg} \cdot \mathrm{g}^{-1}$ for maximum sorption capacity.

The high degree of aromaticity and high point of zero charge (PZC) (Sertoli et al. 2019) might explain the relatively low metal retention by these coffee waste biochars when compared with other biochars in the literature. The lower negative charge density due the aromatic structure of the biochars is supported by the high PZC values (7.7 and 9.2 for SCG and CP respectively) (Sertoli et al. 2019). Such results imply a net negative charge on the biochars' surface only when the $\mathrm{pH}$ of the medium is higher than the PZC (Borba et al. 2019), limiting the attraction and sorption of metallic ions. The higher CEC (Table 1) and higher buffering capacity of CP compared to SCG biochar (Fig. 3) might explain the higher $\mathrm{Pb}$ retention of $\mathrm{CP}$ biochar. A greater affinity for $\mathrm{Pb}$ over $\mathrm{Cd}$ was also observed for biochars derived from vegetable residues and chicken manure (Park et al. 2013) and for sesame straw biochar pyrolyzed at $700^{\circ} \mathrm{C}$ in either competitive or noncompetitive sorption systems (Park et al. 2016). In addition to biochar characteristics, its lower sorption capacity for $\mathrm{Cd}$ in relation to $\mathrm{Pb}$ may also be related to the metallic ions themselves. The size of their ionic radii ( 0.95 and $1.19 \AA$, respectively) may have contributed to the observed difference. Species with larger ionic radii have smaller hydrated radii and are consequently preferentially sorbed when in solution (Park et al. 2016). In addition to a smaller hydrated radius, $\mathrm{Pb}$ (2.33) is more electronegative than $\mathrm{Cd}$ (1.69), and it is a borderline Lewis acid, which favors a greater electrostatic attraction with Lewis hard bases, such as oxygenated functional groups remaining on the surface of the biochars (Oliveira et al. 2018). The hydroxyl and carboxylic acid groups still remained in the biochars (Sertoli et al. 2019), with the latter considered the most important groups for Pb sorption (Pathirana et al. 2019).

Although complexation of metals with oxygen functional groups is important, precipitation as carbonate and hydroxide seems to be the main sorption mechanism according to the experimental results and biochars characteristics, mainly for $\mathrm{CP}$ biochar. However, in this work, the separate contributions of each mechanism were not addressed.

\section{CONCLUSION}

Precipitation as the main sorption mechanism was observed; nevertheless, complexation by functional groups and cation exchange may also have contributed to the sorption of $\mathrm{Pb}$ and $\mathrm{Cd}$ by the biochar.

The Pb sorption capacity was higher for CP than for SCG, while both biochars had low Cd retention capacities. In addition to the higher sorption, $\mathrm{CP}$ also showed the higher content of $\mathrm{Pb}$ that remained sorbed after desorption ( $30 \%$ to $87 \%$ ) than SCG (2.7\% to $51 \%$ ), even under conditions of intense acidity ( $\mathrm{pH} 2.9$ ).

Coffee parchment biochar proved to be more reliable than SCG, mainly for $\mathrm{Pb}$, due to the higher sorption capacity and lower metal release by desorption. These characteristics make CP biochar a viable alternative for environmental use in remediation, especially in conditions of high acidity and metal content such as the mine drainages. Besides that, the biochar production represents an eco-friendly destination for these feedstocks, contributing to the circular economy. 


\section{AUTHORS' CONTRIBUTION}

Conceptualization: Carnier R. and Abreu, C. A.; Data Curation: Carnier R.; Formal Analysis, Carnier R.; Funding Acquisition: Abreu, C. A.; Investigation: Carnier R.; Methodology: Carnier R., Coscione A. R., Abreu, C. A., Melo L. C. A. and Silva A. F.; Project Administration: Abreu, C. A.; Resources: Coscione A. R.; Supervision: Coscione A. R.; Validation: Carnier R.; Visualization: Carnier R., Coscione A. R., Melo L. C. A. and Silva A. F.; Writing - Original Draft: Carnier R.; Writing - Review and Editing: Carnier R., Coscione A. R., Abreu, C. A., Melo L. C. A. and Silva A. F.

\section{DATA AVAILABILITY STATEMENT}

All dataset were generated and analyzed in the current study.

\section{FUNDING}

Fundação de Amparo à Pesquisa do Estado de São Paulo

[https://doi.org/10.13039/501100001807]

Grant No. 2016/19368-6

Coordenação de Aperfeiçoamento de Pessoal de Nível Superior

[https://doi.org/10.13039/501100002322]

Finance Code 001

\section{ACKNOWLEDGMENTS}

Not applicable.

\section{REFERENCES}

Abdel-Raoulf, M. S. and Abdul-Raheim, A. R. M. (2017). Removal of heavy metals from industrial waste water by biomass-based materials: A review. Journal of Pollution Effects \& Control, 5, 1000180. https://doi.org/10.4172/2375-4397.1000180

Araújo, C. S. T., Almeida, I. L. S., Rezende, H. C., Marcionilio, S. M. L. O., Léon, J. J. L. and Matos, T. N. (2018). Elucidation of mechanism involved in adsorption of $\mathrm{Pb}(\mathrm{II})$ onto lobeira fruit (Solanum lycocarpum) using Langmuir, Freundlich and Temkin isotherms. Microchemical Journal, 137, 348-354. https://doi.org/10.1016/j.microc.2017.11.009

Bandara, T., Xu, J., Potter, I. D., Franks, A., Chathurika, J. B. A. J. and Tang, C. (2020). Mechanisms for the removal of Cd(II) and Cu(II) from aqueous solution and mine water by biochars derived from agricultural wastes. Chemosphere, 254, 126745. https://doi.org/10.1016/j. chemosphere.2020.126745

Beesley, L., Moreno-Jiménez, E., Gomez-Eyles, J. L., Harris, E., Robinson, B. and Sizmur, T. (2011). A review of biochars' potential role in the remediation, revegetation and restoration of contaminated soils. Environmental Pollution, 159, $3269-3282$. https://doi.org/10.1016/j.envpol.2011.07.023 
Bian, R., Joseph, S., Cui, L., Pan, G., Li, L., Liu, X., Zhang, A., Rutlidge, H., Wong, S., Chia, C., Marjo, C., Gong, B., Munroe, P. and Donne, S. (2014). A three-year experiment confirms continuous immobilization of cadmium and lead in contaminated paddy field with biochar amendment. Journal of Hazardous Materials, 272, 121-128. https://doi.org/10.1016/j.jhazmat.2014.03.017

Blinová, L., Sirotiak, M., Bartošová, A. and Soldán, M. (2017). Review: Utilization of waste from coffee production. Research Papers Faculty of Materials Science and Technology Slovak University of Technology, 25, 91-101. https://doi.org/10.1515/rput-2017-0011

Borba, L. L., Cuba, R. M. F., Terán, F. J. C.; Castro, M. N. and Mendes, T. A. (2019). Use of adsorbent biochar from Pequi (Caryocar brasiliense) husks for the removal of commercial formulation of glyphosate from aqueous media. Engineering, Technology and Techniques, 62 , e19180450. https://doi.org/10.1590/1678-4324-2019180450

Brunauer, S., Emmet, P. H. and Teller, E. (1938). Adsorption of gases in multimolecular layers. Journal of the American Chemical Society, 60, 309-319. https://doi.org/10.1021/ja01269a023

Chi, T., Zuo, J. and Liu, F. (2017). Performance and mechanism for cadmium and lead adsorption from water and soil by corn straw biochar. Frontiers of Environmental Science \& Engineering, 11. https://doi.org/10.1007/s11783-017-0921-y

Chwastowski, J., Bradło, D. and Żukowski, W. (2020). Adsorption of cadmium, manganese and lead ions from aqueous solutions using spent coffee grounds and biochar produced by its pyrolysis in the fluidized bed reactor. Materials, 13, 2782. https://doi.org/10.3390/ ma13122782

Cuong, D. V., Liu, N.-L., Nguyen, V. A. and Hou, C.-H. (2019). Meso/micropore-controlled hierarchical porous carbon derived from activated biochar as a high-performance adsorbent for copper removal. Science of the Total Environment, 692, 844-853. https://doi. org/10.1016/j.scitotenv.2019.07.125

Dias, D. R., Valencia, N. R., Franco, D. A. Z. and López-Núñez, J. C. (2014). Management and utilization of wastes from coffee processing. In R. F. Shwan and G. H. Fleet (Eds.), Cocoa and coffee fermentations (p. 376-382). Boca Raton: CRC Press.

Domingues, R. R., Sánchez-Monedero, M. A., Spokas, K. A., Melo, L. C. A., Trugilho, P. F., Valenciano, M. N. and Silva, C. A. (2020). Enhancing cation exchange capacity of weathered soils using biochar: Feedstock, pyrolysis conditions and addition rate. Agronomy, 10, 824. https://doi.org/10.3390/agronomy10060824

Domingues, R. R., Trugilho, P. F., Silva, C. A., Melo, I. C. N. A., Melo, L. C. A., Magriotis, Z. M. and Sánchez-Monedero, M. A. (2017). Properties of biochar derived from wood and high-nutrient biomasses with the aim of agronomic and environmental benefits. PLoS ONE, 12, e0176884. https://doi.org/10.1371/journal.pone.0176884

Fdez-Sanromán, A., Pazos, M., Rosales, E. and Sanromán, M. A. (2020). Unravelling the environmental application of biochar as lowcost biosorbent: A review. Applied Sciences, 10, 7810. https://doi.org/10.3390/app10217810

Freundlich, H. (1906). Über die adsorption in lösungen. Zeitschrift für Physikalische Chemie, 57, 385-470. https://doi.org/10.1515/ zpch-1907-5723

Hassan, M., Liu, Y., Naidu, R., Du, J., Qi, F., Donne, S. W. and Islam, M. M. (2021). Mesoporous biopolymer architecture enhanced the adsorption and selectivity of aqueous heavy-metal ions. ACS Omega, 6, 15316-15331. https://doi.org/10.1021/acsomega.1c01642

Hoslett, J. Ghazal, H., Ahmad, D. and Jouhara, H. (2019). Removal of copper ions from aqueous solution using low temperature biochars derived from the pyrolysis of municipal solid waste. Science of the Total Environment, 673, 777-789. https://doi.org/10.1016/j. scitotenv.2019.04.085

Huang, F., Gao, L.-Y., Deng, J.-H., Chen, S.-H., and Cai, K.-Z. (2018). Quantitative contribution of Cd2+ adsorption mechanisms by chickenmanure-derived biochars. Environmental Science and Pollution Research, 25, 28322-28334. https://doi.org/10.1007/s11356-018-2889-y

Huang, J., Yuan, F., Zeng, G., Li, X., Gu, Y., Shi, L., Liu, W. and Shi, Y. (2017). Influence of pH on heavy metal speciation and removal from wastewater using micellar-enhanced ultrafiltration. Chemosphere, 173, 199-206. https://doi.org/10.1016/j.chemosphere.2016.12.137 
[IBI] International Biochar Initiative. (2015). Standardized product definition and product testing guidelines for biochar that is used in soil. Canandaigua: IBI. [Accessed May 06, 2018]. Available at: https://www.biochar-international.org/wp-content/uploads/2018/04/ IBI_Biochar_Standards_V2.1_Final.pdf

Inglezakis, V. J. and Poulopoulos, S. G. (2006). Adsorption and ion exchange. In Adsorption, ion exchange and catalysis: Design of operations and environmental applications (p. 243-353). Amsterdam: Elsevier. https://doi.org/10.1016/B978-044452783-7/50004-5

Jagdale, P., Ziegler, D., Rovere, M., Tulliani, J. M. and Tagliaferro, A. (2019). Waste coffee ground biochar: A material for humidity sensors. Sensors, 19, 801. https://doi.org/10.3390/s19040801

Jazini, R., Soleimani, M. and Mirghaffari, N. (2018). Characterization of barley straw biochar produced in various temperatures and its effect on lead and cadmium removal from aqueous solutions. Water and Environment Journal, 32, 125-133. https://doi.org/10.1111/wej.12307

Jiang, S., Huang, L., Nguyen, T. A. H., Ok, Y. S., Rudolph, V., Yang, H. and Zhang, D. (2016). Copper and zinc adsorption by softwood and hardwood biochars under elevated sulphate-induced salinity and acidic pH conditions. Chemosphere, 142, 64-71. https://doi. org/10.1016/j.chemosphere.2015.06.079

Kim, M.-S., Min, H.-G., Koo, N., Park, J., Lee, S.-H., Bak, G.-I. and Kim, J.-G. (2014). The effectiveness of spent coffee grounds and its biochar on the amelioration of heavy metals contaminated water and soil using chemical and biological assessments. Journal of Environmental Management, 146, 124-130. https://doi.org/10.1016/j.jenvman.2014.07.001

Klingel, T., Kremer, J. I., Gottstein, V., Rezende, T. R., Schwarz, S. and Lachenmeier, D. W. (2020). A review of coffee by-products including leaf, flower, cherry, husk, silver skin, and spent grounds as novel foods within the European Union. Foods, 9, 665. https://doi.org/10.3390/ foods 9050665

Kulikowska, D., Gusiatin, Z. M., Bułkowska, K. and Klik, B. (2015). Feasibility of using humic substances from compost to remove heavy metals (Cd, $\mathrm{Cu}, \mathrm{Ni}, \mathrm{Pb}, \mathrm{Zn}$ ) from contaminated soil aged for different periods of time. Journal of Hazardous Materials, $300,882-891$. https://doi.org/10.1016/j.jhazmat.2015.08.022

Kumar, A., Kumar, A., Cabral-Pinto, M. M. S., Chaturvedi, A. K., Shabnam, A. A., Subrahmanyam, G., Mondal, R., Gupta, D. K., Malyan, S. K., Kumar, S. S., Khan, S. A. and Yadav, K. K. (2020). Lead toxicity: Health hazards, influence on food chain, and sustainable remediation approaches. International Journal of Environmental Research and Public Health, 17, 2179. https://doi.org/10.3390/ijerph17072179

Kwak, J.-H., Islam, M. S., Wang, S., Messele, S. A., Naeth, M. A., El-Din, M. G. and Chang, S. X. (2019). Biochar properties and lead(II) adsorption capacity depend on feedstock type, pyrolysis temperature, and steam activation. Chemosphere, 231, 393-404. https://doi. org/10.1016/j.chemosphere.2019.05.128

Lahori, A. H., Guo, Z., Zhang, Z., Li, R., Mahar, A., Awasthi, M. K., Shen, F., Sial, T. A., Kumbhar, F., Wang, P. and Jiang, S. (2017). Use of biochar as an amendment for remediation of heavy metal-contaminated soils: Prospects and challenges. Pedosphere, 27, 991-1014. https://doi.org/10.1016/S1002-0160(17)60490-9

Langmuir, I. (1916). The constitution and fundamental properties of solids and liquids. Part I. Solids. Journal of the American Chemical Society, 38, 2221-2295. https://doi.org/10.1021/ja02268a002

Li, B., Yang, L., Wang, C.-q., Zhang, Q.-p., Liu, Q.-c, Li, Y.-d. and Xiao, R. (2017). Adsorption of Cd(II) from aqueous solutions by rape straw biochars derived from different modification processes. Chemosphere, 175, 332-340. https://doi.org/10.1016/j.chemosphere.2017.02.061

Liu, S.-H. and Huang, Y.-Y. (2018). Valorization of coffee grounds to biochar-derived adsorbents for CO2 adsorption. Journal of Cleaner Production, 175, 354-360. https://doi.org/10.1016/j.jclepro.2017.12.076

López, J. E., Builes, S., Salgado, M. A. H., Tarelho, L. A. C., Arroyave, C., Aristizábal, A. and Chavez, E. (2020). Adsorption of cadmium using biochars produced from agro-residues. The Journal of Physical Chemistry C, 124, 14592-14602. https://doi.org/10.1021/acs.jpcc.0c02216 
Meng, J., Tao, M., Wang, L., Liu, X. and Xu, J. (2018). Changes in heavy metal bioavailability and speciation from a Pb-Zn mining soil amended with biochars from co-pyrolysis of rice straw and swine manure. Science of The Total Environment, 633, 300-307. https://doi. org/10.1016/j.scitotenv.2018.03.199

Naidu, G., Ryu, S., Thiruvenkatachari, R., Choi, Y., Jeong, S. and Vigneswaran, S. (2019). A critical review on remediation, reuse, and resource recovery from acid mine drainage. Environmental Pollution, 247, 1110-1124. https://doi.org/10.1016/j.envpol.2019.01.085

Nascimento, R. F., Lima, A. C. A., Vidal, C. B., Melo, D. Q. and Raulino, G. S. C. (2014). Adsorção: Aspectos teóricos e aplicações ambientais. Fortaleza: Imprensa Universitária.

Nazir, R., Khan, M., Masab, M., Rehman, H. U., Rauf, N. U., Shahab, S., Ameer, N., Sajed, M., Ullah, M., Rafeeq, M. and Shaeen, Z. (2015). Accumulation of heavy metals ( $\mathrm{Ni}, \mathrm{Cu}, \mathrm{Cd}, \mathrm{Pb}, \mathrm{Zn}, \mathrm{Fe}$ ) in the soil, water and plants analysis of physico-chemical parameters of soil and water collected from Tanda Dam Kohat. Journal of Pharmaceutical Sciences and Research, 7, 89-97.

Nelson, D. W. and Sommers, L. E. (1996). Total carbon, organic carbon, and organic matter. In D. L. Sparks, A. L. Page, P. A. Helmke, R. H. Loeppert, P. N. Soltanpour, M. A. Tabatabai, C. T. Johnston and M. E. Sumner (Eds.), Methods of soil analysis Part 3: Chemical methods (p. 961-1010). Madison: Soil Science of America, American Society of Agronomy.

Oliveira, F. S. D., Azevedo, I. C. D. D., Nascentes, R. and Cabral, L. M. (2018). Avaliação da viabilidade de utilização de resíduos da construção civil na sorção de $\mathrm{Pb}^{2+}, \mathrm{Cd}^{2+}, \mathrm{Cr}^{3+}$ e As ${ }^{5+}$. Engenharia Sanitária e Ambiental, 23, 363-371. https://doi.org/10.1590/s1413-41522018151714

Park, J. H., Choppala, G., Lee, S. J., Bolan, N., Chung, J. W. and Edraki, M. (2013). Comparative sorption of Pb and Cd by biochars and its implication for metal immobilization in soils. Water, Air, \& Soil Pollution, 224, 1711. https://doi.org/10.1007/s11270-013-1711-1

Park, J.-H., Ok, Y. S., Kim, S.-H., Cho, J.-S., Heo, J.-S., Delaume, R. D. and Seo, D.-C. (2016). Competitive adsorption of heavy metals onto sesame straw biochar in aqueous solutions. Chemosphere, 142, 77-83. https://doi.org/10.1016/j.chemosphere.2015.05.093

Paschalidou, P., Pashalidis, I., Manariotis, I. D. and Karapanagioti, H. K. (2020). Hyper sorption capacity of raw and oxidized biochars from various feedstocks for U(VI). Journal of Environmental Chemical Engineering, 8, 103932. https://doi.org/10.1016/j.jece.2020.103932

Pathirana, C., Ziyath, A. M., Jinadasa, K. B. S. N., Egodawatta, P., Sarina, S. and Goonetilleke, A. (2019). Quantifying the influence of surface physico-chemical properties of biosorbents on heavy metal adsorption. Chemosphere, 234, 488-495. https://doi.org/10.1016/j. chemosphere.2019.06.074

Penido, E. S., Melo, L. C. A., Guilherme, L. R. G. and Biachi, M. L. (2019). Cadmium binding mechanisms and adsorption capacity by novel phosphorus/magnesium-engineered biochars. Science of The Total Environment, 671, 1134-1143. https://doi.org/10.1016/j. scitotenv.2019.03.437

Qian, L., Zhang, W., Yan, J., Han, L., Gao, W., Liu, R. and Chen, M. (2016). Effective removal of heavy metal by biochars colloids under different pyrolysis temperatures. Bioresource Technology, 206, 217-224. https://doi.org/10.1016/j.biortech.2016.01.065

Ronsse, F., van Hecke, S., Dickinson, D. and Prins, W. (2013). Production and characterization of slow pyrolysis biochar: Influence of feedstock type and pyrolisis conditions. GCB Bioenergy, 5, 104-115. https://doi.org/10.1111/gcbb.12018

Sengupta, A. K. (2017). Table of solubility product constants at $25^{\circ} \mathrm{C}$. In Ion Exchange in Environmental Processes: Fundamentals, Applications and Sustainable Technology (p. 459-460). Hoboken: John Wiley \& Sons. https://doi.org/10.1002/9781119421252.app3

Sertoli, L., Carnier, R., Abreu, C. A., Coscione, A. R. and Melo, L. C. A. (2019). Coffee waste biochar: Characterization and zinc adsorption from aqueous solution. Coffee Science, 14, 518-529. https://doi.org/10.25186/cs.v14i4.1634

Singh, B., Dolk, M. M., Shen, Q. and Arbestain, M. C. (2017). Biochar pH, electrical conductivity and liming potential. In B, Singh, M. C. Aberstain and J. Lehmann (Eds.), Biochar: A guide to Analytical Methods (p. 23-38). Australia: CSIRO Publishing

Singh, B., Singh, B. P. and Cowie, A. L. (2010). Characterization and evaluation of biochars for their application as a soil amendment. Australian Journal of Soil Research, 48, 516-525. https://doi.org/10.1071/SR10058 
Sohi, S. P., Krull, E., Lopez-Capel, E. and Bol, R. (2010). A review of biochar and its use and function in soil. In D. L. Sparks (Ed.), Advances in Agronomy (p. 47-82). Amsterdam: Elsevier. https://doi.org/10.1016/S0065-2113(10)05002-9

Stylianou, M., Christou, A., Dalias, P., Polycarpou, P., Michael, C., Agapiou, A., Papanastasiou, P. and Fatta-Kassinos, D. (2020). Physicochemical and structural characterization of biochar derived from the pyrolysis of biosolids, cattle manure and spent coffee grounds. Journal of the Energy Institute, 93, 2063-2073. https://doi.org/10.1016/j.joei.2020.05.002

Tabelin, C. B., Igarashi, T., Villacorte-Tabelin, M., Park, I., Opiso, E. M., Ito, M. and Hiroyoshi, N. (2018). Arsenic, selenium, boron, lead, cadmium, copper, and zinc in naturally contaminated rocks: A review of their sources, modes of enrichment, mechanisms of release, and mitigation strategies. Science of The Total Environment, 645, 1522-1553. https://doi.org/10.1016/j.scitotenv.2018.07.103

Tomczyk, A., Boguta, P., and Sokołowska, Z. (2019). Biochar efficiency in copper removal from Haplic soils. International Journal of Environmental Science and Technology, 16, 4913. https://doi.org/10.1007/s13762-019-02434-z

Uchimiya, M., Klasson, K. T., Wartelle, L. H. and Lima, I. M. (2011). Influence of soil properties on heavy metal sequestration by biochar amendment: 2. Copper desorption isotherms. Chemosphere, 82, 1438-1447. https://doi.org/10.1016/j.chemosphere.2010.11.078

[USEPA] United States Environmental Protection Agency. (1992). Method 1311: Toxicity characteristic leaching procedure. Washington: USEPA. [Accessed Jul. 22, 2019]. Available at: https://www.epa.gov/sites/production/files/2015-12/documents/1311.pdf

Veiga, T. R. L. A., Lima, J. T., Dessimoni, A. L. A., Pego, M. F. F., Soares, J. R. and Tugilho, P. F. (2017). Different plant biomass characterizations for biochar production. Cerne, 23, 529-536. https://doi.org/10.1590/01047760201723042373

Wang, L., Wang, Y., Ma, F., Tankpa, V., Bai, S., Guo, X. and Wang, X. (2019). Mechanisms and reutilization of modified biochar used for removal of heavy metals from wastewater: A review. Science of the Total Environment, 668, 1298-1309. https://doi.org/10.1016/j. scitotenv.2019.03.011

Wang, R.-Z., Huang, D.-L., Liu, Y.-G., Zhang, C., Lai, C., Zeng, G.-M., Cheng, M., Gong, X.-M., Wan, J. and Luo, H. (2018). Investigating the adsorption behavior and the relative distribution of $\mathrm{Cd} 2+$ sorption mechanisms on biochars by different feedstock. Bioresource Technology, 261, 265-271. https://doi.org/10.1016/j.biortech.2018.04.032

Wang, S., Gao, B., Zimmerman, A. R., Li, Y., Ma, L., Harris, W. G. and Migliaccio, K. W. (2015). Physicochemical and sorptive properties of biochars derived from woody and herbaceous biomass. Chemosphere, 134, 257-262. https://doi.org/10.1016/j.chemosphere.2015.04.062

Wu, J., Wang, T., Zhang, Y. and Pan, W.-P. (2019). The distribution of Pb(II)/Cd(II) adsorption mechanisms on biochars from aqueous solution: Considering the increased oxygen functional groups by $\mathrm{HCl}$ treatment. Bioresource Technology, 291, 121859. https://doi. org/10.1016/j.biortech.2019.121859

Xu, Y., Seshadri, B., Sarkar, B., Wang, H., Rumpel, C., Sparks, D., Farreal, M., Hall, T., Yang, X. and Bolan, N. (2018). Biochar modulates heavy metal toxicity and improves microbial carbon use efficiency in soil. Science of The Total Environment, 621, 148-159. https://doi. org/10.1016/j.scitotenv.2017.11.214

Yin, G., Bi, L., Song, X., Luo, H., Ji, P., Lin, Q., Liu, Q. and Tang, G. (2019). Adsorption of Cd(II) from aqueous solution by Pennisetum sp. straw biochars derived from different modification methods. Environmental Science and Pollution Research, 26, 7024-7032. https://doi. org/10.1007/s11356-019-04158-6

Zama, E. F., Zhu, Y.-G., Reid, B. J. and Sun, G.-X. (2017). The role of biochars properties in influencing the sorption and desorption of $\mathrm{Pb}$ (II), Cd (II) and As (III) in aqueous solution. Journal of Cleaner Production, 148, 127-136. https://doi.org/10.1016/j.jclepro.2017.01.125

Zeng, X., Xiao, Z., Zhang, G., Wang, A., Li, Z., Liu, Y., Wang, H., Zeng, Q., Liang, Y. and Zou, D. (2018). Speciation and bioavailability of heavy metals in pyrolytic biochars of swine and got manures. Journal of Analytical and Applied Pyrolysis, 132, 82-93. https://doi. org/10.1016/j.jaap.2018.03.012 
Zhang, H., Yue, X., Li, F., Xiao, R., Zhang, Y. and Gu, D. (2018). Preparation of rice straw-derived biochar for efficient cadmium removal by modification of oxygen-containing functional groups. Science of The Total Environment, 631-632, 795-802. https://doi.org/10.1016/j. scitotenv.2018.03.071

Zhao, B., O’Connor, D., Zhang, J., Peng, T., Shen, Z., Tsang, D. C. W. and Hou, D. (2018). Effect of pyrolysis temperature, heating rate, and residence time on rapeseed stem derived biochar. Journal of Cleaner Production, 174, 977-987. https://doi.org/10.1016/j.jclepro.2017.11.013

Zhou, D., Liu, D., Gao, F., Li, M. and Luo, X. (2017). Effect of biochars-derived sewage sludge on heavy metal adsorption and immobilization in soils. International Journal of Environmental Research and Public Health, 14, 681. https://doi.org/10.3390/ijerph14070681 